Article

\title{
Domestic Wastewater Reuse in Concrete Using Bench-Scale Testing and Full-Scale Implementation
}

\author{
Ayoup M. Ghrair * and Othman Al-Mashaqbeh \\ Scientific Research Center, Royal Scientific Society, P.O. Box 1438, Al-Jubaiha, Amman 11941, Jordan; \\ othman.mashaqbeh@rss.jo \\ * Correspondence: ayoup.ghrair@rss.jo or ghrir@yahoo.com; Tel.: +962-6-5344701
}

Academic Editor: Andreas N. Angelakis

Received: 3 July 2016; Accepted: 21 August 2016; Published: 24 August 2016

\begin{abstract}
Demand for fresh water by the construction sector is expected to increase due to the high increase in the growth of construction activities in Jordan. This study aims to evaluate the potential of scale-up of the application of treated domestic wastewater in concrete from bench-scale to a full-scale. On the lab scale, concrete and mortar mixes using Primary and Secondary Treated Wastewater (PTW, STW) and Distilled Water (DW) were cast and tested after various curing ages $(7,28,120$, and 200 days). Based on wastewater quality, according to IS 456-2000, the STW is suitable for mortar and concrete production. Mortar made with STW at curing time up to 200 days has no significant negative effect on the mortar's compressive strength. Conversely, the PTW exceeded the maximum permissible limits of total organic content and $E$ coli. for concrete mixing-water. Using PTW results, a significant increase in the initial setting time of up to $16.7 \%$ and a decrease in the concrete workability are observed. In addition, using PTW as mixing water led to a significant reduction in the compressive strength up to $19.6 \%$. The results that came out from scaling up to real production operation of ready-mix concrete were in harmony with the lab-scale results.
\end{abstract}

Keywords: wastewater; compressive strength; mixing water; mortar; concrete

\section{Introduction}

Wastewater reuse is seen as the main long-term strategy for the conservation of limited freshwater resources. In Jordan, the reuse of treated wastewater for irrigation has been practiced since the 1980s in a bid to overcome severe water shortage [1]. Treated wastewater has been officially regulated by the Water Authority as a resource by adopting standards regulating the reuse of treated domestic wastewater for irrigation since 1995 [2]. The quality of treated wastewater discharged by newly operated plants in Jordan is considered very high according to the reuse requirements stated in the Jordanian Reclaimed Wastewater Standard-JS 893\2006 [2], which presents a good opportunity to expand the schemes of treated wastewater reuse [3]. The amount of treated wastewater is expected to be around $262 \mathrm{MCM} /$ year in 2020 [4]. One of the main objectives of the existing water demand management policy is to expand the reuse of treated wastewater and the exploitation of new water resources in order to have a positive influence on the water sector and other important sectors in Jordan's development (i.e., industry and construction) [5].

Over the past decade, Jordan has experienced a boom in the construction sector. Large construction activities including new hotels as well as residential and commercial buildings have been started. According to Jordan's Economic and Commerce Bureau [6], the growth rates of Jordan's construction sector have increased remarkably during the last 10 years. It is also expected to continue increasing in the coming five years due to the continuous growth of Jordan's population and business sector.

The concrete industry in Jordan is currently consuming around $8 \mathrm{MCM} /$ year of fresh water for production, washing activities and wet curing. This volume is expected to increase due to the high 
increase in the growth of the construction sector. According to the guidelines of Jordanian Reclaimed Wastewater Standard-JS 893 \2006 [2], it is still not allowed to reuse treated wastewater in construction activities. Therefore, substitution of fresh water with treated wastewater partially or totally in the concrete industry is a well thought-out move, which is expecting to save around $8 \mathrm{MCM}$ of fresh water for drinking purposes.

Globally, the concrete industry is consuming one billion tons of mixing water annually. In addition, enormous quantities of fresh water are being used for washing of truck mixers, concrete pumps, equipment, aggregate, curing concrete and ready mix concrete [7,8]. The increasing use of cement in different types of construction activities using fresh water sources justifies the research into the reuse of treated wastewater as an alternative to fresh water. Silva and Naik [9] reported that additional research into wastewater reuse in the concrete industry is required and possibly in the near future there will be a declaration of wastewater reuse in concrete.

Many studies have extensively evaluated utilizing wastewater in concrete mixtures in lab scale. These studies have tested different types of wastewater such as raw sewage [10], treated wastewater [11-13], preliminary treated wastewater, secondary treated wastewater, and tertiary treated wastewater [14], three types of treated wastewater [7], and treated effluent [15]. These studies have concluded from lab scale experiments that the application of treated wastewater in concrete is feasible and meet the standard specifications and building codes. However, utilizing domestic wastewater in concrete mixtures using a pilot scale has been rarely studied in the literature.

This study aims to evaluate the potential of scale-up of the application of treated domestic wastewater in concrete from lab scale to a pilot production operation scale (Ready mix concrete). Primary Treated Wastewater (PTW) and Secondary Treated Wastewater (STW) collected from As-Samra wastewater treatment plant were used in mortar and concrete mixes.

\section{Materials and Methodology}

\subsection{As-Samra Wastewater Treatment Plant}

As-Samra Wastewater Treatment Plant (WWTP) is the largest wastewater treatment plant in Jordan. The plant was upgraded in 2003 from natural treatment (Wastewater Stabilization Ponds) to mechanical treatment (Activated Sludge). The facility was designed to treat an average design flow of 267,000 cubic meters per day of domestic wastewater, serving a population of about 2.2 million living in the Greater Amman and Zarqa areas, with the ability to receive a peak flow of 840,000 cubic meters every day. As-Samra WWTP consists of a primary settling tank, eight aeration tanks and eight secondary settling tanks, four anaerobic sludge digesters, biogas and hydro-powered generators, and an odor control system.

Two types of treated wastewater were collected from As-Samra WWTP for lab and pilot experiments. The first sample represents the Primary Treated Wastewater (PTW), which was collected from the effluent of the primary settling tank, while the second sample represents the Secondary Treated Wastewater (STW), which was collected from the effluent of the secondary settling tank. The collected samples were transferred to the laboratory. These samples were analysed for $\mathrm{pH}$ and electrical conductivity (EC). Total dissolved solids (TDS), total suspended solids (TSS), biological oxygen demand $\left(\mathrm{BOD}_{5}\right)$, chemical oxygen demand (COD), Total phosphorous (T-P), Ammonia $\left(\mathrm{NH}_{3}\right)$, Chloride $\left(\mathrm{Cl}^{-}\right)$, and, finally, Escherichia coli bacteria. All these analyses were carried out according to the standard methods for the examination of water and wastewater [16].

Fresh water (FW) sample was collected from Kingdom Concrete company mixer site, Shafabadran/Amman, Jordan. Fresh water (FW) and distilled water (DW) were used as control for bench-scale and full-scale experiments, respectively. 


\subsection{Raw Material Preparation and Testing}

\subsubsection{Aggregates}

Aggregates are granular materials that are usually chemically inactive. They are dispersed throughout the cement matrix mainly to reduce the cost of the concrete because aggregates are cheaper than cement [17]. The properties of the raw materials used in preparing mortar and concrete mixtures were tested in RSS laboratories according to national and international standards. These materials include coarse aggregate, fine aggregate, and cement.

Regarding concrete mixtures, two sizes of coarse aggregates and two types of fine aggregates were used, whereas one type was used in the preparation of mortar. The physical properties of aggregates are shown below in Table 1, while the combined aggregates' gradations are shown in the Figures 1 and 2.

Table 1. The physical properties of the used aggregate.

\begin{tabular}{cccc}
\hline Aggregate Type & $\begin{array}{c}\text { Median Particle Size } \\
(\mathbf{m m})\end{array}$ & $\begin{array}{c}\text { Bulk Specific Gravity } \\
\text { (SSD) }\end{array}$ & $\begin{array}{c}\text { Absorption } \\
(\mathbf{\%})\end{array}$ \\
\hline Coarse Aggregate (Fouleyeh) & 12.50 & 2.50 & 3.6 \\
Coarse Aggregate (Hemseyeh) & 9.50 & 2.67 & 0.9 \\
Coarse Aggregate (Adaseyeh) & 4.73 & 2.67 & 1.2 \\
Fine Aggregate (Semsmeyeh) & 2.36 & 2.65 & 1.5 \\
Fine Aggregate (Swealeh sand) & 0.30 & 2.62 & 1.0 \\
\hline
\end{tabular}

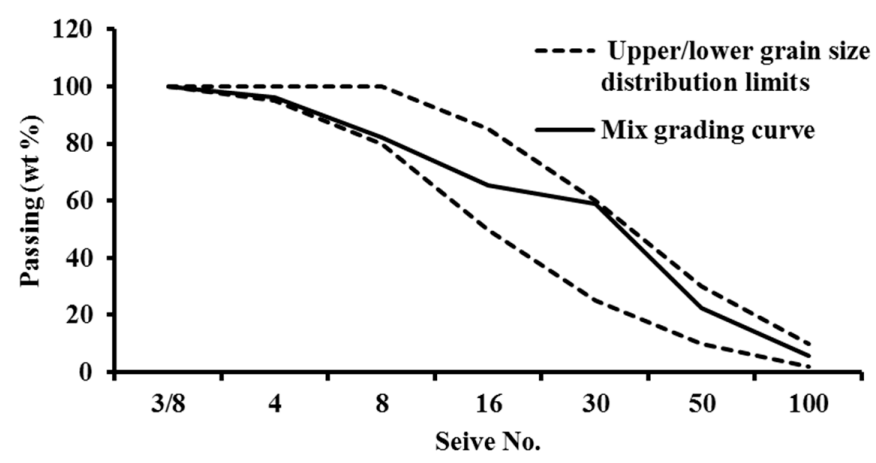

Figure 1. Pattern of grading curve for combined coarse aggregate.

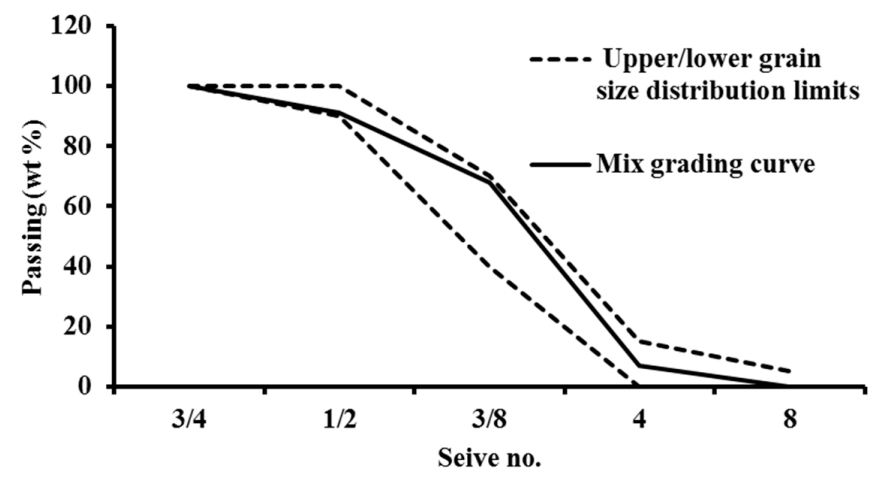

Figure 2. Pattern of grading curve for combined fine aggregate.

\subsubsection{Cement}

Pozzolanic Portland Cement (PPC, Type II) manufactured by Jordan cement factory company was used in preparing mortar and concrete mixtures. The chemical properties of the cement used are shown in Table 2. 
Table 2. The chemical properties of the Pozzolanic Portland Cement, Type II.

\begin{tabular}{cccc}
\hline Property & Test Result (\%) & Limitations & Test Method \\
\hline Chloride Content $(\mathrm{Cl})$ & 0.031 & $\leq 0.10$ & {$[16]$} \\
Sulfate Content $\left(\mathrm{SO}_{3}\right)$ & 3.20 & $\leq 3.5$ & {$[16]$} \\
Insoluble Residue & 11.93 & - & {$[16]$} \\
\hline
\end{tabular}

\subsection{Experimental Work for Mortar}

Control mortar mix was designed according to volumetric proportion ranges suggested by Jordanian standards. Many trial mixes were carried out to obtain the best proportions depending on the properties of the used materials. After the preparation of control mix (using distilled water), two types of wastewater were utilized for separate mixes. The other components of mixtures were kept constant as those in the control one except for water type, which was added to each mix to obtain the same workability as the control mix.

During the mortar mix design process, the flow table was used as a workability indicator for the whole mixes. The test was conducted according to the American standard [18].

The mixing of mortar mixes was performed according to EN 196 [19]. A standard mixer was used in the mixing process. After mix preparation, it was filled in the moulds and compacted by Jolting table, and after that the moulds were covered with glass plates and kept in standard conditions $\left(21 \pm 2{ }^{\circ} \mathrm{C}\right.$ and $50 \% \pm 10 \%$ R.H.) till the next day. After $24 \mathrm{~h}$ of casting, samples were taken out from moulds and stored for curing in a water tank under standard temperature $21 \pm 2{ }^{\circ} \mathrm{C}$. For each mortar mix, 24 prisms $(40 \mathrm{~mm} \times 40 \mathrm{~mm} \times 160 \mathrm{~mm})$ were cast. Each six prisms were tested after various curing times $(7,28,120$ and 200 days). Fresh mortar properties were tested directly after mix preparation such as initial setting time and soundness. Generally, initial setting is the time elapsed from adding water to the cement until the time at which the needle cannot penetrate more than $6 \pm 2 \mathrm{~mm}$ from the bottom of the vicat's mould [20]. Soundness refers to the ability to resist volume expansion. It is determined by Le-Chatelier method IS: 4031, where a specimen of hardened cement paste is boiled for $3 \mathrm{~h}$. Then, allow it to cool down to the room temperature in order to measure the distance between the indicator points.

The compressive strength was evaluated according to EN 1015-11 [21]. The specimens were tested at $7,28,120$, and 200 days of age, and the average of three specimens at each age was calculated in order to compare the results of the different mixes that were prepared. A stereo microscope analysis was conducted for the mortar prisms. Six samples were collected randomly at various cross sections from each mortar mixture at curing age 28 days ( 6 samples $\times 3$ mortar mixture). Each slide dimension was $4 \mathrm{~cm} \times 4 \mathrm{~cm}$.

\subsection{Mixes Experimental Work for Concrete}

Based on the mix design, the grading of combined aggregates (Hemseyeh, Adaseyeh, Semsmeyeh and Swealeh Sand) was chosen to get the best grading mix in order to achieve workability of fresh concrete (slump 15-18 mm) and compressive strength (30 MPa). The slump test measures the collapse behaviour of a compacted cone of concrete under the gravity influence. The test is carried out using a mould known as a slump cone. The cone is placed on a hard surface and filled with fresh concrete. After that, the mould is lifted vertically upwards, and the concrete consequently subsides. This subsidence distance is termed as slump. It indicates consistency or workability [22]. Compressive strength is the capacity of a material to resist loads tending to reduce size. It refers to the compressive stress at which the material fails completely [23].

The grading patterns of combined coarse and fine aggregates are shown in Figures 1 and 2.

Proportions of cement, aggregate, and water were chosen to produce the design grade of concrete by taking the following features into consideration: workability at fresh state, characteristic strength at a certain age, and durability at the long term. Concrete characteristic strength was specified according 
to established modern theories in concrete mix preparation and depended on probability theories by applying the following equation:

$$
\mathbf{f}_{\mathrm{cm}}=\mathbf{f}_{\mathrm{cu}}+\mathbf{S K}
$$

where, $\left(\mathbf{f}_{\mathrm{cu}}\right)$ stands for Characteristic Strength of Concrete Mix $\left(\mathrm{N} / \mathrm{mm}^{2}\right) ;\left(\mathbf{f}_{\mathrm{cm}}\right)$ stands for Target Strength depending on Normal Distribution Curve; (S) stands for Standard Deviation (N/ $\left.\mathrm{mm}^{2}\right)$; and (K) stands for Statistical Coefficient. Based on the strength results, the following mix was adapted as shown in Table 3.

Table 3. Concrete Design mix contents for Bench-scale and full-scale (ready mix concrete).

\begin{tabular}{ccc}
\hline & \multicolumn{2}{c}{ Quantit $\left(\mathbf{k g} / \mathbf{m}^{\mathbf{3}}\right)$} \\
\hline Mix Contents & Bench-scale & Full-scale \\
Fouleyehy * & - & 463 \\
Hemseyeh * & 514.728 & - \\
Adaseyeh * & 370.3 & 520 \\
Semsmeyeh * & 252.1 & 318 \\
Swealeh Sand * & 502.7 & 574 \\
Cement & 418.18 & 280 \\
Total Water & 233 & 190 \\
Superplasticizer & Zero & 5 \\
\hline Note: * Local names for coarse and fine aggregates see Table 1.
\end{tabular}

\subsubsection{Concrete Trial Mixes}

A number of concrete trial mixes were performed to achieve fresh properties such as consistency and flow as well as hardened concrete strength. For each mix, and after measuring concrete temperature and making a slump test, 12 cubes $(150 \times 150 \times 150) \mathrm{mm}$ were prepared and cured according to JS 1652-2:2004 [24], at $21 \pm 2{ }^{\circ} \mathrm{C}$ and humidity of (100\%). Three cubes for each mix were tested at 7 days for strength indication, while the other cubes were tested at 28, 120, and 200 days to obtain their compressive strength.

After the preparation of concrete control mix, distilled water (DW) was replaced by two types of treated domestic wastewater (PTW and STW) at different percentages $(100 \%, 75 \%$, and $50 \%)$ in separate mixes. Concrete mixing procedure was performed by using pan mixer. After fresh property evaluation, concrete mixes were cast in the moulds and compacted by using a vibration table. After that, moulds were covered with plastic sheets and kept under standard conditions $\left(21 \pm 2{ }^{\circ} \mathrm{C}\right.$ and $50 \% \pm 10 \%$ R.H.) till the next day. Twenty-four hours after casting, samples were taken out from moulds and stored for curing in a water tank under standard temperature $21 \pm 2{ }^{\circ} \mathrm{C}$ until testing date.

For each concrete mix, and after the completion of mixing, fresh concrete properties including slump were tested according to fresh concrete testing standards EN 12350-2: 2009 [25].

For compressive strength test, specimens were tested at 7, 28, 120, and 200 days, and the average of three specimens at each age was calculated in order to compare the results of the different mixtures that were prepared. The whole strength tests were performed according to JS 1652 parts 3, 5, and 6 [24].

\subsubsection{Scaling up to Real Concrete Production}

It is important to investigate the effect of PTW, STW and fresh water (FW) when scaling up to make concrete in a real production operation. Therefore, three concrete mixtures were carried out and tested at various curing times in a private ready mix company. A fully automated Belt type was used to transport the aggregates from weighting machine to the main mixer according to mix design (Table 3). Ninety minutes is a maximum time from the moment of water addition to mixture until casting it in the site. During this experiment, all these ordinary operation conditions were the same at the mixer except the mix-water type. The produced three mixtures were used for pavement of the side road in the rural area near Amman city. This experiment was carried out to ensure that the results of 
the full-scale are in harmony with bench-scale experiments and to give more insight into the impact of PTW and STW on the real job site and production scale. After a fresh property evaluation, concrete mixes were cast in the moulds and compacted by using a vibration table. Samples were stored for curing in a water tank under standard temperature $21 \pm 2{ }^{\circ} \mathrm{C}$ until the testing date.

Based on the mix design of the ready-mix concrete company, grading of aggregate (Fouleyeh, Adaseyeh, Semsemeyeh, and Swealeh Sand) was chosen to achieve workability of fresh concrete (slump 18-22 cm) and compressive strength (25 MPa).

After the completion of mixing for each concrete mix, fresh concrete properties including slump were tested. For compressive strength test, specimens were tested at 7, 28, and 120 . The average of three specimens at each age was calculated.

\section{Results and Discussion}

\subsection{Treated Domestic Wastewater Quality}

Mixing water quality plays an essential role in the preparation of concrete [26]. Drinkable water can be used as mixing water for concrete production. Furthermore, some water types that are not suitable for drinking may be fit for concrete making $[27,28]$. Table 4 shows that the TSS concentration of PTW $(148 \mathrm{mg} / \mathrm{L})$ and STW $(10.5 \mathrm{mg} / \mathrm{L})$ were below the tolerated limit of suspended fine particles in mixing water $(2000 \mathrm{mg} / \mathrm{L})$ according to the Portland Cement Association (PCA) [27]. However, a suspended solid of $50,000 \mathrm{mg} / \mathrm{L}$ is still tolerated in case of reusing of wastewater from mixer washout operations. The results also showed that the TDS concentrations of PTW and STW (900 and 974 mg/L) are lower than the maximum permissible concentration $(2000 \mathrm{mg} / \mathrm{L})$. The total organic content of the STW $(46.9 \mathrm{mg} / \mathrm{L})$ is lower than the maximum permissible level while the organic concentration of PTW (538 mg/L) exceeded the maximum permissible level. The values of chloride and $\mathrm{pH}$ are under the maximum permissible limits. E. coli is still considered as the most important indicator of public health [29].

Based on the acceptable criteria for water to be used in concrete (Table 4), the STW is suitable for concrete production whereas the PTW should be tested and compared with specimens made with FW or DW to ensure that the impurities in PTW do not adversely affect the mechanical properties of the concrete [30]. The PTW should be pretreated to reduce the microorganism content before the water can be in direct contact with humans [31]. Regarding the Jordanian standard specifications, there are no available limits for dissolved impurities in mixing water and their possible negative impact on concrete properties.

Table 4. Water quality analysis of Treated wastewater (Primary Treated Wastewater (PTW) and Secondary Treated Wastewater (STW)), Fresh water (FW), Distilled Water (DW) and the mixing water permissible limits for concrete.

\begin{tabular}{ccccccc}
\hline Parameter & Unit & PTW & STW & FW & DW & $*$ Maximum Concentration \\
\hline $\mathrm{TSS}$ & $\mathrm{mg} / \mathrm{L}$ & 148 & 10.5 & $<2$ & $<2$ & 2000 \\
$\mathrm{TDS}$ & $\mathrm{mg} / \mathrm{L}$ & 900 & 974 & 499 & $<2$ & 2000 \\
$\mathrm{COD}$ & $\mathrm{mg} / \mathrm{L}$ & 538 & 46.9 & $<5$ & $<5$ & 500 \\
$\mathrm{BOD}$ & $\mathrm{mg} / \mathrm{L}$ & 226 & 2.6 & $<2$ & $<2$ & - \\
$\mathrm{Cl}$ & $\mathrm{mg} / \mathrm{L}$ & 251 & 291 & 107 & $<5$ & 500 \\
$\mathrm{SO}_{4}$ & $\mathrm{mg} / \mathrm{L}$ & 106 & 106.2 & 78.4 & $<5$ & 2000 \\
$\mathrm{NH}_{3}$ & $\mathrm{mg} / \mathrm{L}$ & 54.4 & $<4.5$ & $<0.08$ & $<0.08$ & No specific limit \\
$\mathrm{pH}$ & - & 7.2 & 7.5 & 7.59 & 6 & $6-8$ \\
E. coli & $\mathrm{MPN} / 100 \mathrm{~mL}$ & $1.70 \times 10^{7}$ & $<1$ & $<1$ & $<1$ & $* *<200$ \\
\hline
\end{tabular}

Notes: * Mixing water permissible limits according to $[28,29,32,33] ;{ }^{* *}$ The maximum limits for an open system application of wastewater [34]. 


\subsection{Effects of Treated Wastewater on Cement Paste}

The results presented in Table 5 show that the initial setting time of cement paste mixed with PTW and STW were up to +5 and +30 min compared to control. Furthermore, the water/cement ratio shows a slight increase of up to $0.4 \%$ and $0.6 \%$ for PTW and STW, respectively. Moreover, the results of the soundness test of cement by the Le-Chateliers method show no significant differences between using PTW, STW, and control. According to the requirement of the Jordanian standard (No. 30-1/2007) [35], the maximum expansion must be $\leq 10 \mathrm{~mm}$.

Table 5. Fresh properties of cement paste.

\begin{tabular}{ccccccc}
\hline Water Type & $\begin{array}{c}\text { Wt. of } \\
\text { Cement (gm) }\end{array}$ & $\begin{array}{c}\text { Water } \\
\text { (CC) }\end{array}$ & $\begin{array}{c}\text { Water/Cement } \\
\mathbf{( \% )}\end{array}$ & $\begin{array}{c}\text { Initial Setting } \\
\text { Time }(\mathbf{m i n})\end{array}$ & $\begin{array}{c}* \text { Needle } \\
\text { Penetration }(\mathbf{m m})\end{array}$ & $\begin{array}{c}\text { Soundness } \\
(\mathbf{m m})\end{array}$ \\
\hline PTW & 500 & 149 & 29.8 & 210 & 4 & 1 \\
STW & 500 & 148 & 29.6 & 185 & 4 & 1 \\
Control & 500 & 146 & 29.2 & 180 & 6 & 1 \\
\hline
\end{tabular}

These results are in harmony with ASTM C94 [24] requirements on initial setting time where the initial setting time of cement paste made with the questionable water must not be more than $60 \mathrm{~min}$ earlier than that made with the same cement using DW. Shekarchi et al. [7] and Al-Ghusain et al. [14] reported that the dissolved salts can increase the initial setting time up to $+70 \mathrm{~min}$ in case of using treated domestic wastewater on cement paste.

\subsection{Effects of Treated Wastewater on Mortar Properties}

The results depicted in Figure 3 reveal that mortar made with STW at curing time $(7,28$, and 200 days) has no significant negative effect on the mortar's compressive strength. However, at 120 days there is a slight reduction in compressive strength. Using PTW as mixing water led to a reduction in the compressive strength at curing time $(7,28,120$, and 200 days). This could be due to the effect of organic contents, which may have contributed to mortar strength reduction.

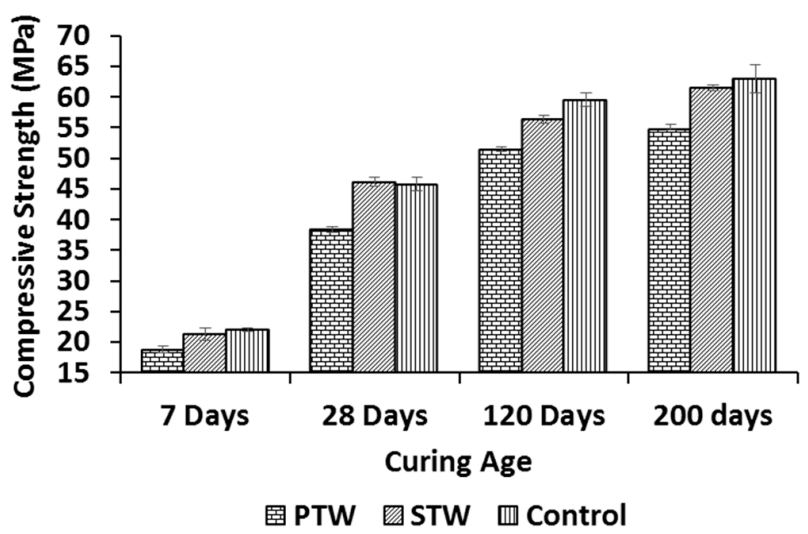

Figure 3. Influence of PTW and STW on mortar compressive strength at various wet curing age.

Mortar relative strength index $\left(R_{\mathrm{S}}\right)$ can be defined as the ratio of the compressive strength of mortar or concrete to that of the control [36]. Table 6 represents the mortar $R_{\mathrm{s}}$ of mixes using PTW and STW at the wet curing ages of 7, 28, and 120 days. The relative index in Table 6 indicates that using PTW as mixing water for mortar production led to a significant reduction in the compressive strength between $13.6 \%$ and $16.2 \%$, while addition of the STW led to a slight increase in $R_{S}$ at curing age (28 days) and a slight decrease in $\mathrm{R}_{\mathrm{S}}$ at long term curing time (120 days). According to the ASTM C109 [20], water is suitable for production concrete if the mortar which was made with it has strength 
at 7 days curing time that is equal or less than $10 \%$ reduction compared to control samples made with drinkable water.

Table 6. Mortar and concrete relative strength index of mixes using PTW and STW.

\begin{tabular}{ccccc}
\hline \multirow{2}{*}{ Curing Age (Day) } & \multicolumn{2}{c}{ Mortar Relative Strength Index (\%) } & \multicolumn{2}{c}{ Concrete Relative Strength Index (\%) } \\
\cline { 2 - 5 } & PTW & STW & PTW & STW \\
\hline 7 & -14.9 & -3.7 & -4.5 & -9.8 \\
28 & -16.2 & +0.7 & -13.5 & -5.1 \\
120 & -13.6 & -5.3 & -19.6 & -7.2 \\
200 & -12.9 & -2.24 & -13.2 & -10.1 \\
\hline
\end{tabular}

A stereo microscope is employed to produce three-dimensional photos and low magnification observation. Figure 4 apparently shows that there are no significant differences in air void size and distribution between mortar specimens made with PTW, STW, and DW. There is no micro-crack effect on the surface of mortar specimens. The mortar specimen structure and the matrix between aggregates are structurally intact.
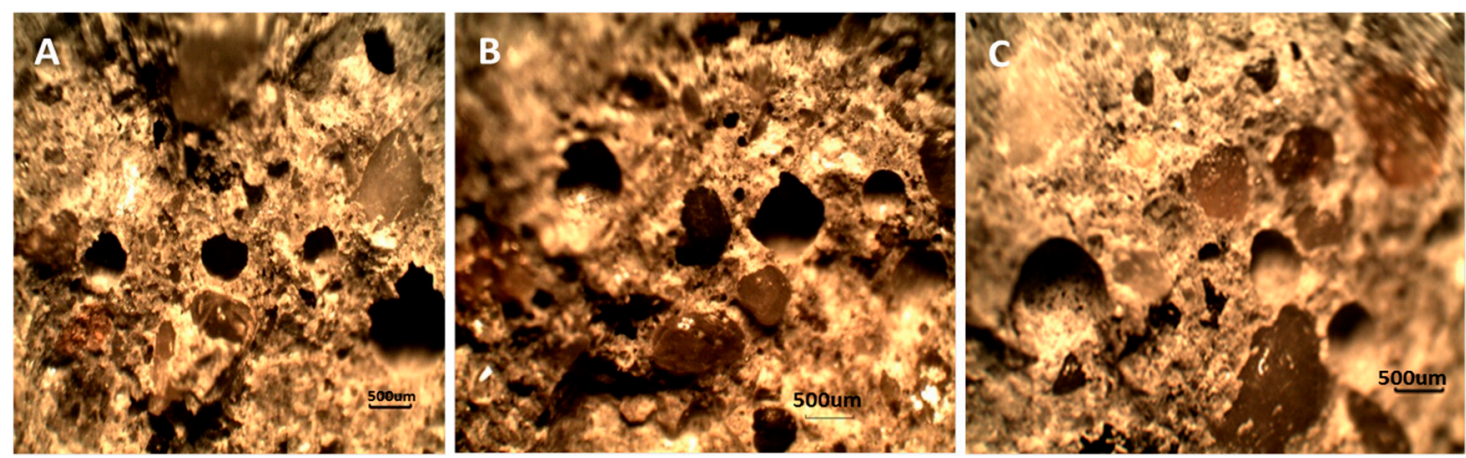

Figure 4. Stereo microscope images of mortar specimens performed with (A): PTW; (B): STW; and $(\mathrm{C})$ : DW. The image was taken at $30 \times$ magnification.

\subsection{Effects on Concrete Properties}

The best indicator for concrete workability is slump value. The results of slump test on concrete using PTW, STW, and Control (FW for full-scale or DW for bench-scale) as mixing water are presented in Figure 5. In the case of the bench-scale mixtures, the results reveal that using PTW and STW led to a decrease in slump by 2.5 and $1.5 \mathrm{~cm}$, respectively. In the case of the full-scale mixtures, using PTW and STW led to a decrease in slump by 4 and $1 \mathrm{~cm}$, respectively. The difference between bench-scale and full-scale the slump value is attributed to apply superplasticizer by 0 and $5 \mathrm{~kg} / \mathrm{m}^{3}$, respectively. Application of PTW led to a decrease in the concrete workability and increase in the concrete viscosity. The total dissolved solids and $\mathrm{SO}_{4}{ }^{2-}$ in the PTW and STW are higher than the control mixing water (Table 4). The achieved observations are consistent with previous studies $[7,10]$. One possible explanation is that the dissolved solids in the PTW reduce the concrete slump value. Tang and Gartner [37] and Lawrence [38] reported that the major dissolved solids in the solution phase $\left(\mathrm{Ca}^{2+}, \mathrm{K}^{+}, \mathrm{Na}^{+}, \mathrm{SO}_{4}{ }^{2-}\right.$, and $\left.\mathrm{OH}^{-}\right)$were very important factors in governing the characteristics of early cement paste hydration. They found that also presence of relatively soluble sulfates retarded the initial $\mathrm{C}_{3} \mathrm{~A}$ hydration. 

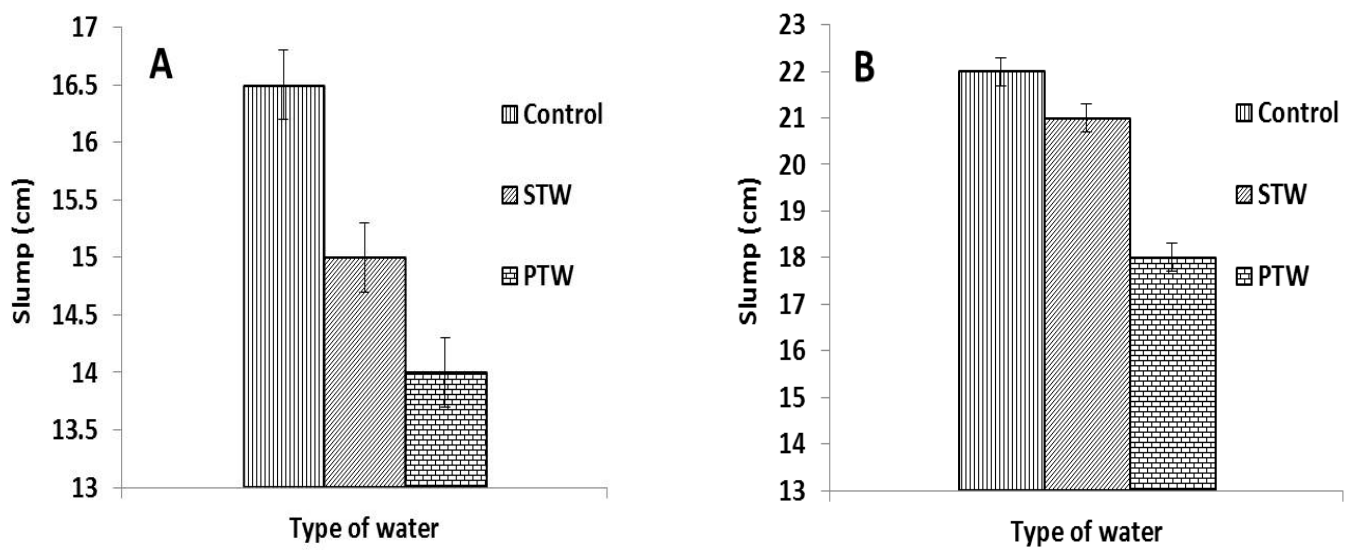

Figure 5. Slump of concrete using PTW, STW, and Control as mixing water. (A): Lab scale mixtures; (B): scale up mixtures to ready mix concrete.

In the case of the lab mixtures, the compressive strength of concrete utilizing PTW, STW, and DW at curing ages 7, 28, 120, and 200 days are shown in Figure 6. In comparison with concrete made by DW, the compressive strength of concrete made by PTW and STW at 7 days shows a slight decrease with no significant differences. The compressive strength of STW at 28 days curing age shows no significant differences. However, at curing ages of 120 and 200 days, it shows a significant reduction up to $10 \%$. The concrete made with PTW shows a significant reduction in the compressive strength of up to $19.6 \%$ at 120 days (Table 6). In the case of scale-up mixtures to ready-mix concrete (Figure 7): In comparison with concrete made by FW, the compressive strength of concrete made by PTW and STW at 7 days shows with no significant differences. The compressive strength of STW at 28 days curing age shows a slight decrease with no significant differences. In addition, at curing age of 120 days, it shows a significant reduction of up to $7.2 \%$. The concrete made with PTW shows a significant reduction in the compressive strength of up to $19.6 \%$ at 120 days. This reduction in the compressive strength is placed on the concrete which is made by PTW outside the allowable threshold.

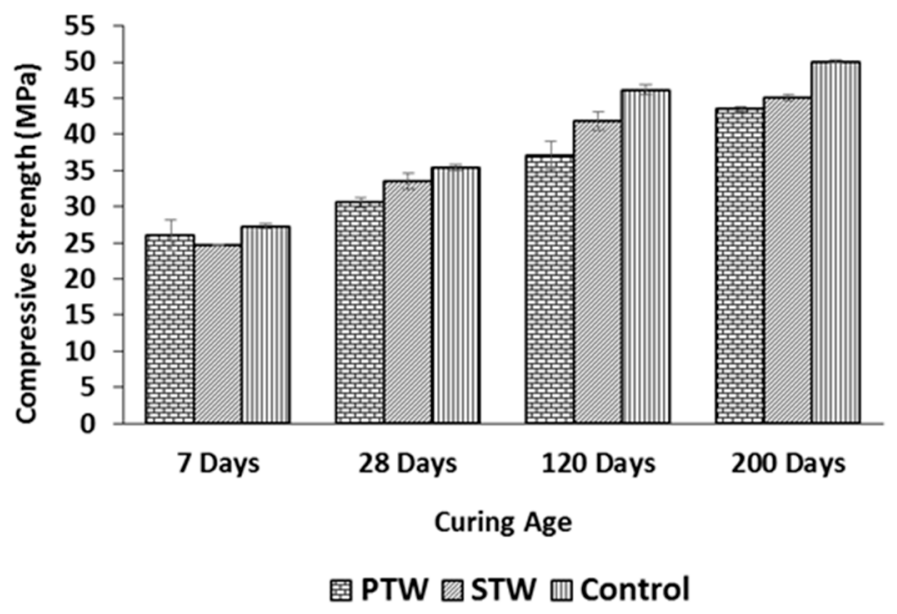

Figure 6. The compressive strength of lab scale concrete utilizing PTW, STW, and DW at curing age 7, 28,120 , and 200 days.

The present results are not in disagreement with AbdolChini and Mbwambo [39] who reported that the properties of concrete are not affected by the use of recycled water (washing wastewater from ready-mixed concrete plant). However, these study results show that the type of recycled water may influence concrete properties. 


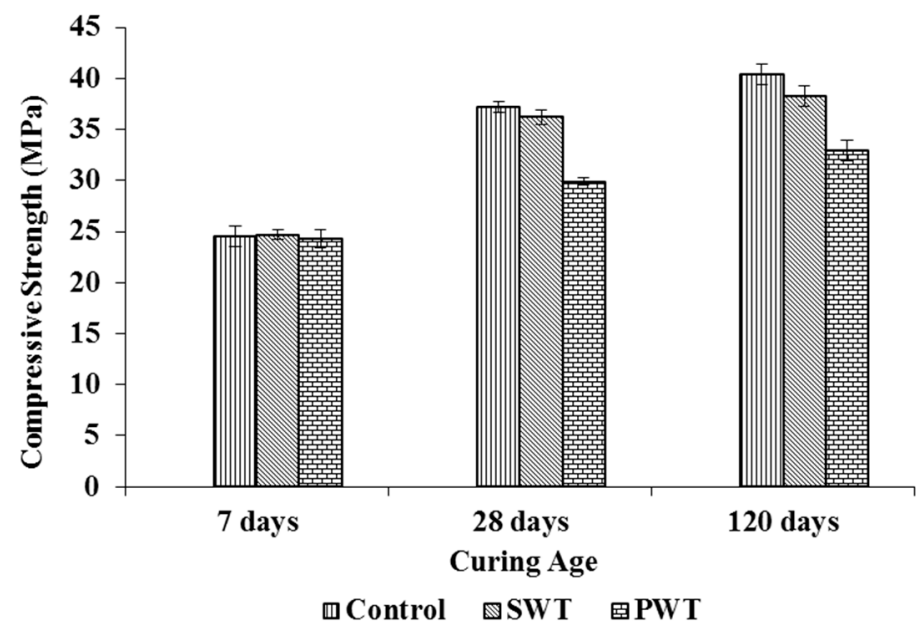

Figure 7. The compressive strength of scale up mixtures to ready mix concrete utilizing PTW, STW, and FW at curing age 7,28 , and 120 days.

Domestic wastewater has different pollutant contents. Therefore, its impact on concrete properties should be different. According to the IS 456-2000 [40] and Kucche et al. [26], the reduction of compressive strength of concrete should not exceed $15 \%$ of the mean compressive strength of concrete specimen made with drinkable water.

The effect of dilution of PTW, using dilution ratio of (PTW:DW) 1:0, 3:1 and 1:1, on the development of strength is presented in Figure 8. It is clear that there are no significant effects of dilution of PTW on compressive strength at various curing ages. Based on these results, dilution of PTW is not the solution to enhance the PTW properties as mixing water.

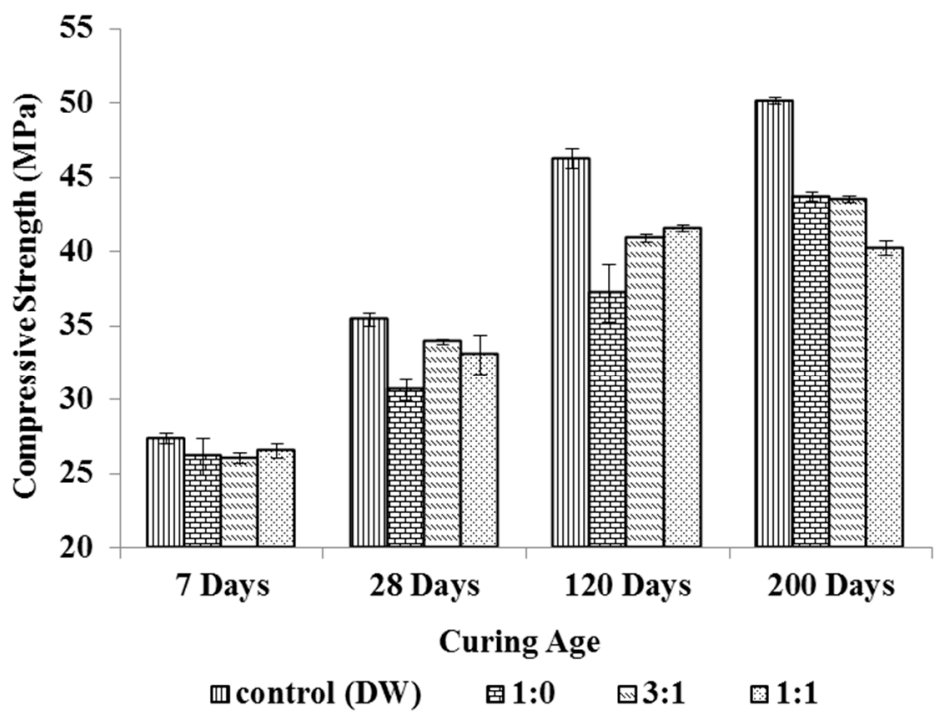

Figure 8. The effect of dilution ratio of PTW ((PTW: DW); 1:0, 3:1, 1:1) on the development of concrete compressive strength at curing age $7,28,120$, and 200 days.

The water absorption parameter is one of the most important indicators of the concrete's potential durability and quality [28]. The average water absorption of concrete performed with PTW, STW, and DW is $1.70 \%, 1.74 \%$ and $1.74 \%$, respectively. The result shows that the effect of using domestic wastewater as mixing water on water absorption is not significant. This result is in agreement with Shekarchi et al. [7] who reported that utilizing treated wastewater as mixing water does not affect the concrete's durability and water absorption. 


\section{Conclusions}

This study has evaluated the use of PTW and STW for concrete and mortar production in bench and full scales. The water quality analysis showed that STW is suitable for concrete and mortar production according to permissible limits of mixing water for concrete while PTW is not.

The initial setting time of cement paste performed with PTW and STW is increased by 30 and $5 \mathrm{~min}$, respectively. The water/cement ratio shows a slight increase by $0.6 \%$. These results are satisfied and in harmony with ASTM C94 requirements. Mortar made with STW at curing time up to 200 days has no negative effect on the mortar's compressive strength. However, using PTW as mixing water led to a reduction in the compressive strength. The relative strength index indicates that using PTW as mixing water for mortar production led to a significant reduction in the compressive strength by up to $16.2 \%$. Furthermore, there is no significant effect of using PTW or STW on the soundness value of mortar. According to the ASTM C109 or AASHTOT 106, STW is suitable for mortar production. PTW has a more significant negative effect on concrete workability than the STW; however, the effect of PTW and STW on concrete water absorption and durability is not significant. Moreover, there is no significant effect of dilution of PTW with DW on compressive strength improvement at various curing ages. Therefore, dilution of PTW is not the way to enhance its properties as mixing water. At curing age up to 200 days, the compressive strength of concrete made with STW and PTW shows a significant negative impact up to $10 \%$ and $19.6 \%$, respectively. According to the IS 456-2000, STW is suitable for concrete production. Regardless of the type of mixing water (PTW, STW, FW, or DW), there is continuous increase in the concrete and mortar's compressive strength. However, the compressive strength growth rate is water type dependent.

In conclusion, this study has shown that STW is a potential alternative for fresh water in the concrete industry. Therefore, the current guidelines for wastewater recuse should be revised by the governmental authorities to encourage the use of STW as a substitute for fresh water in concrete production.

Acknowledgments: This project is funded by the 'Support to Research, Technological Development and Innovation in Jordan' (SRTD-II), an EU-funded project managed by the Higher Council for Science and Technology. The Authors would like to express their thanks to The Higher Council for Science and Technology's SRTD II project implementation office for their help, facilities, and follow-up during the project period. Cordial acknowledgment goes to Kingdom Concrete Company and Eng Muath Al-Kronz for providing all facilities during the pilot-scale experiments. The authors greatly appreciate the help received from the following persons at RSS Testing Sector of RSS: Eng. Nedal AlKose and Mahmoud Farfoura for their valuable contribution in sample preparation, testing and data analysis. In addition, many thanks go to Mohammd K. Sarireh from the Civil Engineering Department, Tafila Technical University, for his valuable and fruitful discussions during the project implementation.

Author Contributions: Ayoup M. Ghrair and Othman Al-Mashaqbeh conceived and designed the experiments; performed the experiments; analyzed the data; and wrote the paper.

Conflicts of Interest: The authors declare no conflict of interest.

\section{References}

1. McCornick, P.G.; Hijazi, A.; Sheikh, B. From wastewater reuse to water reclamation: Progression of water reuse standards in Jordan. In Wastewater Use in Irrigated Agriculture: Confronting the Livelihood and Environmental Realities; Scott, C.A., Faruqui, N.I., Raschid-Sally, L., Eds.; CABI Publishing: Wallingford, UK, 2004; pp. 113-125.

2. Jordan Institution for Standards and Metrology. Water-Reclaimed Domestic Wastewater; Jordanian Standard JS 893; Jordan Institution for Standards and Metrology: Amman, Jordan, 2006.

3. Ammary, B.Y. Wastewater reuse in Jordan: Present status and future plans. Desalination 2007, 211, $164-176$. [CrossRef]

4. Hashemite Kingdom of Jordan-Ministry of Water and Irrigation (MWI). Water for Life. Jordan's Water Strategy 2008-2022; MWI: Amman, Jordan, 2009. 
5. Hashemite Kingdom of Jordan-Ministry of Water and Irrigation (MWI). National Water Strategy of Jordan 2016-2025. 2016. Available online: http://www.mwi.gov.jo/sites/en-us/Hot\%20Issues/Strategic\% 20Documents\%20of\%20\%20The\%20Water\%20Sector/National\%20Water\%20Strategy(\%202016-2025)-25.2. 2016.pdf (accessed on 25 June 2016).

6. Economic and Commerce Bureau (ECB). Jordan's Economic and Commerce Bureau-Construction and Building Materials; Embassy of the Hashemite Kingdom of Jordan: Washington, DC, USA, 2016; Available online: http:/ / www.jordanecb.org/Public/English.aspx?Site_Id=1\&Page_Id=555\&menu_id=38 (accessed on 17 June 2016).

7. Shekarchi, M.; Yazdian, M.; Mehrdadi, N. Use of biologically treated wastewater in concrete. Kuwait J. Sci. Eng. 2012, 39, 97-111.

8. Naik, T.R. Sustainability of the cement and concrete industries. In Sustainable Construction Materials and Technologies; Chun, Y.M., Claisse, P., Naik, T.R., Ganjian, E., Eds.; Taylor and Francis: Coventry, UK, 2007; pp. 19-25.

9. Silva, M.; Naik, T.R. Sustainable use of resources-Recycling of sewage treatment plant water in concrete. In Proceedings of the Second International Conference on Sustainable Construction Materials and Technologies, Ancona, Italy, 28 June 2010.

10. Cebeci, O.Z.; Saatci, A.M. Domestic sewage as mixing water in concrete. ACI Mater. J. 1989, 86, 503-506.

11. Tay, J.; Yip, W. Use of reclaimed wastewater for concrete mixing. J. Environ. Eng. 1987, 113, $1156-1161$. [CrossRef]

12. Mahasneh, B.Z. Assessment of Replacing Wastewater and Treated Water with Tap Water in Making Concrete Mix. Research Gate Net. 2005. Available online: http:/ /www.ejge.com/2014/Ppr2014.223mar.pdf (accessed on 22 August 2016).

13. Saricimen, H.; Shameem, M.; Barry, M.; Ibrahim, M. Testing of Treated Effluent for Use in Mixing and Curing of Concrete. E-prints. 2008. Available online: http://eprints.kfupm.edu.sa/1745/1/91-104_Testing of_Treated_Effluent_for_use_in_Mixing_and_Curing_of_Concrete_H-Saricimen_M-Shameem_M-Barry_ and_M-Ibrahim.PDF (accessed on 11 May 2016).

14. Al-Ghusain, I.; Terro, M.J. Use of treated wastewater for concrete mixing in Kuwait. Kuwait J. Sci. Eng. 2003, 30, 213-228.

15. Lee, O.S.; Salim, M.R.; Ismail, M.; Ali, M.I. Reusing treated effluent in concrete technology. Jurnalteknologi 2001, 34, 1-10.

16. American Public Health Association (APHA). Standard Methods for the Examination of Water and Wastewater; APHA: Washington, DC, USA, 2006.

17. Moavenzadeh, F. Concise Encyclopedia of Building and Construction Materials; The MIT Press: Cambridge MA, USA, 1990; p. 689.

18. ASTM International. Standard Specification for Flow Table for Use in Tests of Hydraulic Cement; ASTM C230/C230M; ASTM International: West Conshohocken, PA, USA, 2008.

19. European Committee for Standarization. Methods of Testing Cement. Determination of Strength; BS EN 196-1\&2; European Committee for Standarization: Brussels, Belgium, 2005.

20. American Society for Testing and Materials. Compressive Strength of Hydraulic Cement Mortar; ASTM C-109; American Society for Testing and Materials: West Conshohocken, PA, USA, 2010.

21. European Committee for Standarization. Methods of Test of Mortar for Masonry; BS EN 1015-11; European Committee for Standarization: Brussels, Belgium, 2007.

22. Gambhir, M.L. Concrete Technology, 3rd ed.; Tata McGraw-Hill: New Delhi, India, 2004.

23. Callister, W.D., Jr. Materials Science E Engineering an Introduction; John Wiley \& Sons: Hoboken, NJ, USA, 2003.

24. Jordan Institution for Standards and Metrology. Concrete-Testing Hardened Concrete, Part 2: Making and Curing Specimens for Strength Tests; JS 1652-1; Jordan Institution for Standards and Metrology: Amman, Jordan, 2004.

25. European Committee for Standarization. Testing Fresh Concrete, Slump-Test; EN 12350-2; European Committee for Standarization: Brussels, Belgium, 2009.

26. Kucche, K.J.; Jamkar, S.S.; Sadgir, P.A. Quality of water making concrete: A review of literature. Int. J. Sci. Publ. 2015, 5, 1-10.

27. Kosmatka, S.H.; Kerkhoff, B.; Panarese, W.C. Design and Control of Concrete Mixtures. Engineering Bulletin 001, 14th ed.; Portland Cement Association (PCA): Skokie, IL, USA, 2003. 
28. Neville, A.M. Properties of Concrete, 5th ed.; Pearson Education Limited: London, UK, 2011; p. 2833.

29. Cement Concrete \& Aggregates Australia. Use of Recycled Water in Concrete Production Report; Cement Concrete \& Aggregates Australia: Sydney, Australia, 2007.

30. ASTM International. Time of Setting of Hydraulic Cement by Vicat Needle; ASTM C 191; ASTM International: West Conshohocken, PA, USA, 2008.

31. Viessman, W.J.; Hammer, M.J. Water Supply and Pollution Control, 4th ed.; Harper and Row: New York, NY, USA, 1985.

32. ASTM International. Standard Specification for Ready Mix Concrete; ASTM C94/C94M-14b; ASTM International: West Conshohocken, PA, USA, 1994.

33. European Committee for Standardization. Mixing Water for Concrete-Specification for Sampling, Testing and Assessing the Suitability of Water, Including Water Recovered from Processes in the Concrete Industry, as Mixing Water for Concrete; European Standard EN 1008; European Committee for Standardization: Brussels, Belgium, 2002.

34. Environmental Protection Agency (EPA). Guidelines for Water Reuse Technical Issues in Planning Water Reuse Systems; EPA/625/R-04/108; U.S. Agency for International Development: Washington, DC, USA, 2004. Chapter 3.

35. Jordan Institution for Standards and Metrology. Composition Specifications and Conformity Criteria for Common Cements; JS 30-1; Jordan Institution for Standards and Metrology: Amman, Jordan, 2007.

36. Alqedra, M.M.; Arafa, M.; Mattar, M. Influence of low and high organic wastewater sludge on physical and mechanical properties of concrete mixes. J. Environ. Sci. Technol. 2011, 4, 354-365. [CrossRef]

37. Tang, F.J.; Gartner, E.M. Influence of Sulphate Source on Ponland Cement Hydration. Adv. Cem. Res. 1988, 1, 67-74. [CrossRef]

38. Lawrence, C.D. Changes in Composition of the Aqueous Phase during Hydration of Cement Pastes and Suspensions. Highw. Res. Board Spec. Rep. 1966, 90, 378-391.

39. AbdolChini, S.; Mbwambo, W.J. Environmentally friendly solutions for the disposal of concrete wash water from ready mixed concrete operations. In Proceedings of the CIB W89 Beijing International Conference, Beijing, China, 21-24 October 1996.

40. Bureau of Indian Standard. Plain and Reinforced Concrete Code of Practice; IS 456; Bureau of Indian Standard: New Delhi, India, 2000.

(C) 2016 by the authors; licensee MDPI, Basel, Switzerland. This article is an open access article distributed under the terms and conditions of the Creative Commons Attribution (CC-BY) license (http:/ / creativecommons.org/licenses/by/4.0/). 